\title{
Congresso Mundial de Oftalmologia, Panamericano e Brasileiro de Prevenção da Cegueira - Brasil: "missão cumprida!"
}

\author{
Cristina Muccioli, Mauro Campos, Mauro Goldchmit, Paulo E. C. Dantas, Samir J. Bechara, Vital Paulino Costa
}

Voltamos todos à rotina em nossos respectivos países, cidades, hospitais, laboratórios e clínicas, depois de uma completa imersão em Oftalmologia da qual tivemos a oportunidade de participar no último mês de fevereiro, com a passagem meteórica do tríplice e único encontro do Congresso Mundial de Oftalmologia, Panamericano e Brasileiro de Prevenção da Cegueira em nosso país; sem contar um pré-congresso de peso, realizado dias antes do WOC 2006, da Associação Internacional de Estrabismo (ISA) e o Conselho Latino-Americano de Estrabismo (CLADE), com um número expressivo de especialistas de todo o mundo.

O WOC 2006 congregou mais de 12.000 participantes entre oftalmologistas, profissionais de áreas afins e acadêmicos, oriundos de 121 países. Uma mistura de raças e etnias desfilando pelos anfiteatros e microfones. Desse total, 7.368 (61\%) eram brasileiros. Apesar da atração da beleza do carnaval brasileiro, seguramente o que mobilizou e motivou a participação de grande massa de colegas brasileiros e daqueles que deixaram seus países, para compartilhar conhecimentos, foi seguramente a excelência da programação científica. Foram 1.547 conferencistas que, em 25 salas, realizaram 355 atividades, a maioria delas com ocupação máxima das salas. A Comissão Científica do WOC 2006 aprovou 3.377 trabalhos para serem apresentados sob forma de pôster, 167 como tema-livre (apresentação oral) e 60 vídeos.

Um evento desse porte e com tal sucesso não nasce de um dia para outro. Foram anos de trabalho intenso, desde a preparação da candidatura do Brasil para sediar o Congresso Mundial no final dos anos 90 aos cuidados com detalhes mínimos que foram estrategicamente pensados para oferecer a melhor infra-estrutura de eventos aos congressistas. Nos bastidores, a equipe operacional contou com 1.174 pessoas que atuaram na secretaria executiva, segurança, limpeza, montadora oficial, sinalização, transporte, estacionamento, banco, agência de turismo, audiovisual e informática. $O$ pavilhão da exposição comercial, com a apresentação das últimas novidades tecnológicas, contou com a participação de 210 empresas e 4.040 pessoas trabalhando em seus stands.

Uma página gloriosa de nossa história foi virada e os números foram apresentados para ter-se a dimensão do trabalho realizado. Mas não restam apenas os números. O que realmente importa é que a oftalmologia brasileira deu uma clara demonstração de capacidade organizacional, propiciando uma programação científica do mais alto nível, esforço esse que certamente permanecerá na mente de todos, dos professores mais renomados aos aprendizes da Oftalmologia, e nos corações dos que vivenciaram e honraram com bravura o dia-a-dia do longo planejamento e trabalhosa execução para alcançar o sucesso que esse evento obteve.

Foi um momento único na história da Oftalmologia mundial e nacional, que dificilmente se repetirá em nosso país em um curto período de tempo, mas que, para os que dele participaram, tampouco será esquecido. Cabe-nos registrar e deixar os cumprimentos à Oftalmologia brasileira, representada pelo $\mathrm{CBO}$ e todos os oftalmologistas brasileiros, e ao Comitê Executivo do WOC que, pelo exemplo de excelência e dedicação, podem orgulhosos dizer: "missão cumprida!".

\section{Visite a site eletrônica das ABO}

uسu.ebganline.com . br 